\title{
Using White Star (Nymphoides humboldtiana) for lake landscaping
}

\section{Carla D Tedesco $^{1} \mathbb{D}$; Claudia Petry ${ }^{1} \mathbb{D}$; Edson C Bortoluzzi ${ }^{1} \mathbb{D}$; Alfredo Castamann ${ }^{2} \mathbb{D}$}

${ }^{1}$ Universidade de Passo Fundo (UPF), Passo Fundo-RS, Brazil; tedesco@upf.br; petry@upf.br; edsonb@upf.br; ${ }^{2}$ Universidade Federal da Fronteira Sul (UFFS), Erechim-RS, Brazil; alfredo.castamann@uffs.edu.br

\begin{abstract}
White Star (Nymphoides humboldtiana), an aquatic-environmental native species of Brazilian flora, was selected in order to be used as ornamental plant in lakes. White Star plants were submitted to two water levels (high water level, up to $30 \mathrm{~cm}$ water depth and, low water level until substrate saturation) and two light intensities (full sun and $50 \%$ shading) to evaluate vegetative and flowering development. The experimental design was completely randomized, in a subplot scheme, being the water level the main plot and luminosity the subplot. Seven replicates were performed, and the sample unit consisted of one plant. Data related to number of leaves and flowers, length and diameter of petioles and leaf area were submitted to analyze of variance and regression. We observed an increase in number of leaves and flowers in the treatment of high water level in full sun, and an increase of petiole length in high water level with shading. No difference between leaf area of plants grown under full sun and with shading $(\mathrm{p}<0.05)$ was observed. At low water level, plants presented lower vegetative development than those grown at high water level, besides the flowering inhibition in shaded condition. These results demonstrated that White Star can be used in ornamental lakes with a water depth of at least $20 \mathrm{~cm}$ above the rhizome and exposed to full sun.
\end{abstract}

Keywords: lakes, landscaping, cultivation environment, ornamental.

\section{RESUMO}

Uso de Estrela Branca (Nymphoides humboldtiana) para paisagismo em lagos

Estrela Branca (Nymphoides humboldtiana), espécie nativa da flora brasileira, proveniente de ambientes aquáticos, foi selecionada visando seu uso como planta ornamental em lagos. Plantas de Estrela Branca foram submetidas a dois níveis de água (nível alto, até $30 \mathrm{~cm}$ de lâmina de água e nível baixo, até a saturação do substrato) e duas intensidades de luz (pleno sol e com 50\% de sombreamento) para avaliação de seu desenvolvimento vegetativo e floração. O delineamento experimental foi inteiramente casualizado, com arranjo em esquema de sub parcelas, tendo o nível d'água como parcela principal e a luminosidade como sub parcela. Foram realizadas sete repetições, sendo a unidade amostral constituída de uma planta. Os dados referentes ao número de folhas e flores, comprimento e diâmetro de pecíolo e à área foliar foram submetidos à análise de variância e de regressão. Constatou-se aumento do número de folhas e de flores no tratamento de nível alto de água a pleno sol, e aumento do comprimento de pecíolo em nível alto de água com sombreamento. Não se observou diferença entre a área foliar das plantas cultivadas a pleno sol e com sombreamento $(\mathrm{p}<0.05)$. Em nível baixo de água, as plantas apresentaram desenvolvimento vegetativo inferior às cultivadas em nível alto de água, além da inibição da floração na condição sombreada. Esses resultados demonstram que a Estrela Branca pode ser utilizada em lagos ornamentais, com lâmina d'água de no mínimo $20 \mathrm{~cm}$ acima do rizoma e exposta a sol pleno.

Palavras chave: lagos, paisagismo, ambiente de cultivo, ornamental.

\section{Received on February 23, 2018; accepted on January 15, 2019}

$\mathrm{F}$ lower market is an important segment in economy. It consists of a large productive chain and is always in search of innovations. The estimated value for this chain in 2018 was 7.2 billion reais (Junqueira \& Peetz, 2018).

Evaluating the potential of Brazilian native species enriches our biodiversity, it can also minimize commercial production costs of these plants for its higher adaptability to cultivation environment (Stumpf et al., 2009, 2015), as well as to mitigate the environmental impact caused by the extraction of these plants for ornamental purposes.
Studies on ornamental potential of herbaceous plants are many and show potential of different species, such as: Baccharis articulata, $B$. usteris, Hipericum connatum (Stumpf et al., 2009), Andropogon bicornis, Aspilia montevidensis, Bidens laevis, Brasiliorchis porphyrostele, Bromelia antiacantha, Hybanthus bicolor, Petunia axillaris, Salvia procurrens (Stumpf et al., 2015) and Tropaeolum pentaphyllum (Prestes et al., 2015). However, the same advance is not observed for aquatic herbaceous plants. Over the past ten years, fewer publications about studies on the ornamental potential of aquatic herbaceous plants can be found in journals (Stumpf et al., 2015; Devi et al., 2015; Blidar, 2017). This fact limits the knowledge about the cultivation of these species and consequently their supply in the market.

The genus Nymphoides presents more than 50 species distributed in the world (Tippery \& Les, 2011), in which aquatic and semi aquatic herbaceous plants with well developed aerenchyma predominate (Souza \& Lorenzi, 2005). Among these species Nymphoides humboldtiana, Brazilian native species, 
can be found in all biomes (Flora do Brasil, 2017), and is commonly known as White Star.

The plant has two stem structures, a rhizome and a stoloniferous stem, horizontal to the substrate, with petioles that, when not branching on the surface of the water, emit only a floating leaf (Souza \& Lorenzi, 2005; Tippery \& Les, 2011; Barcelos \& Bove, 2017). Petioles can reach up to $300 \mathrm{~cm}$ length and are submerged (Pott \& Pott, 2000). The leaves attached to the petiole, when in aquatic environment, remain with the abaxial surface in contact with water (Barcelos \& Bove, 2017). Flowers emerge at the end of spring from the submerged portion of the petiole, a few centimeters from the water surface and remain open for only one day. Flowers are white-colored pentameras, 2.0 to $2.5 \mathrm{~cm}$ in diameter (Pott \& Pott, 2000). According to Wang et al. (2005), the process of flower formation is the same as in N. peltata. The differentiation begins on the day before the opening, below the water surface, when cylindrical pedicels, measuring from 4 to $7 \mathrm{~cm}$, with floral buds, are developed. On flowering day, the buds are raised above the water level and flowering occurs.

White Star is found in waterlogged areas, still-water or low-water movements, (Irgang \& Gastal Júnior, 1996; Marwat et al., 2009). White Star is classified as a rooted plant with floating leaves (Irgang \& Gastal Júnior, 1996).

White Star was selected in this study, based on Composite Index of Ornamental Potential of Tropical Species (Chamas \& Matthes, 2000), using the evaluation carried out in the field, according to what was pointed out in Tedesco (2011).

The goal of this study was to evaluate the adaptability of this species to different waterlogging conditions and different luminosities, aiming to use this plant for landscaping.

\section{MATERIAL AND METHODS}

The experiment was installed at Pavilhão de Aquáticas da Faculdade de Agronomia e Medicina Veterinária of Universidade de Passo FundoRS (2813'52'S, 51'22'50W) on September 9, 2008. The experimental design was completely randomized, in a split-plot arrangement, with water allocation level in the main plot and luminosity in subplot. Leaves and petioles were evaluated weekly, after 10 days of experiment installation. Flowers were registered every two days after flowering beginning, from September 23, 2008 to April 5, 2009. The experiment was carried out in polyethylene pots (5-liter capacity). The 16-meter-height pots were filled with Rhodic Hapludox substrate (Streck et al., 2008), collected in the experimental area at Universidade de Passo Fundo, in the layer from 0 to $20 \mathrm{~cm}$. We put in each pot one Nymphoides humboldtiana rhizome, previously washed in running water and sanitized using hypochlorite solution (diluted 5\%). The rhizome, without leaves, presented at least three internodes, 4 to $6 \mathrm{~cm}$ length. The rhizomes were collected in Capiguí dam, in the municipality of Mato CastelhanoRS (2834'68'S, 52²2'02'W), on January, 2008. The matrix rhizomes were kept in production in Pavilhão de Aquáticas (Aquatic Pavilion) until the experiment installation.

The species development was studied under two environmental conditions: water level, which is variable in aquatic/terrestrial transition zone and luminosity. In relation to light intensity, the authors tried to simulate the shading due to the presence of margin plants, large trees, pergolas and even wet decks, little permeable to radiation and exposure to full sun.

Two water levels were evaluated, considering that the high level consisted of a permanent maintenance of a water depth from 20 to $30 \mathrm{~cm}$ (submerged pots), and the low level in a water saturated substrate (pots filled with water-soaked soil). Water level was controlled using a water faucet, independently for each treatment. Two luminosity conditions were evaluated, full sun and shading (using black shading screen $50 \%$ sombrite $\left.^{\circledR}\right)$. Each treatment consisted of seven replicates. The experimental unit consisted of a 5-liter pot containing rhizome, totalizing
28 experimental units.

During the experimental period, we evaluated number of leaves/plant; leaf area of the largest leaf, length $(\mathrm{cm})$ and diameter $(\mathrm{mm})$ of the petiole base and number of flowers. After the weekly evaluation of these traits, pots were rotated, in order to avoid a possible local effect in the experiment. For evaluation, we considered the leaves with $50 \%$ or more green area, those in expansion and those totally expanded. For leaf area evaluations, the authors measured length and width of the largest leaf of each pot, since removing the leaves from the plants would affect flowering. Leaf area was calculated indirectly (length multiplied by width/correction factor 1.37). Correction factor was obtained using the average value of twelve leaves in different development stages and different treatments. Correction factor was calculated using division of the real area, obtained by measuring the leaf area, by the calculated area (length $\mathrm{x}$ width).

The presence of other plants and fauna was controlled by manual harvesting, when found in pots or in the tank.

Obtained data were submitted to analysis of regression and variance, and then, the Tukey test at 5\% probability was used to compare the averages, with the aid of SISVAR software (Ferreira, 2014).

\section{RESULTS AND DISCUSSION}

Leaves were emitted in all White Star rhizomes, 14 days after transplant. This aquatic species showed better development, greater number of leaves and flowers, when grown in $30 \mathrm{~cm}$ water depth under full sun. Less quantity of leaves was produced only in low water level in shady conditions (Table 1, Figure 1). Luminosity reduction favored an increase of leaf area and petiole length when grown in $30-\mathrm{cm}$ water depth. Probably, as in Nymphoides peltata, the adaption to full sun is more determinant than water depth (Zhonghua et al., 2007).

Plants grown without water depth showed, in Spring (October, 
30 - December, 9), leaves consumed by the polyphagous caterpillar Spodoptera cosmioides (Walker, 1858), Lepidoptera: Noctuidae (Catalogue of Life, 2017), identified by Lisete $M$. Lorini (Laboratório de Entomologia of Universidade de Passo Fundo). This caterpillar is commonly found in low densities in crops such as soybeans, beans, cotton, sorghum, wheat and corn (Bavaresco et al., 2003; Silva et al., 2017).

In this study, the presence of this caterpillar was associated with low luminosity. The caterpillar consumed pieces of leaves or the whole leaf, affecting negatively the leaf area in that period of the experiment.

When plants were grown under
$30 \mathrm{~cm}$ water depth, the leaves showed more than twice the leaf area of those cultivated under water saturation conditions, and in this case, when submitted to low luminosity, a higher reduction in leaf area was noticed (Figure 1). In N. peltata, the authors noticed physiological adaption to water level variation, which may suggest different behavior for this species (Yu et al., 2014). This biomass accumulation of White Star in a high luminosity environment and high water depth favored floral exuberance, since no flowering or minimum flowering was noticed, when the plant was grown in a shaded place under low water depth.

Generally, in aquatic plants, the appropriate combination of temperature

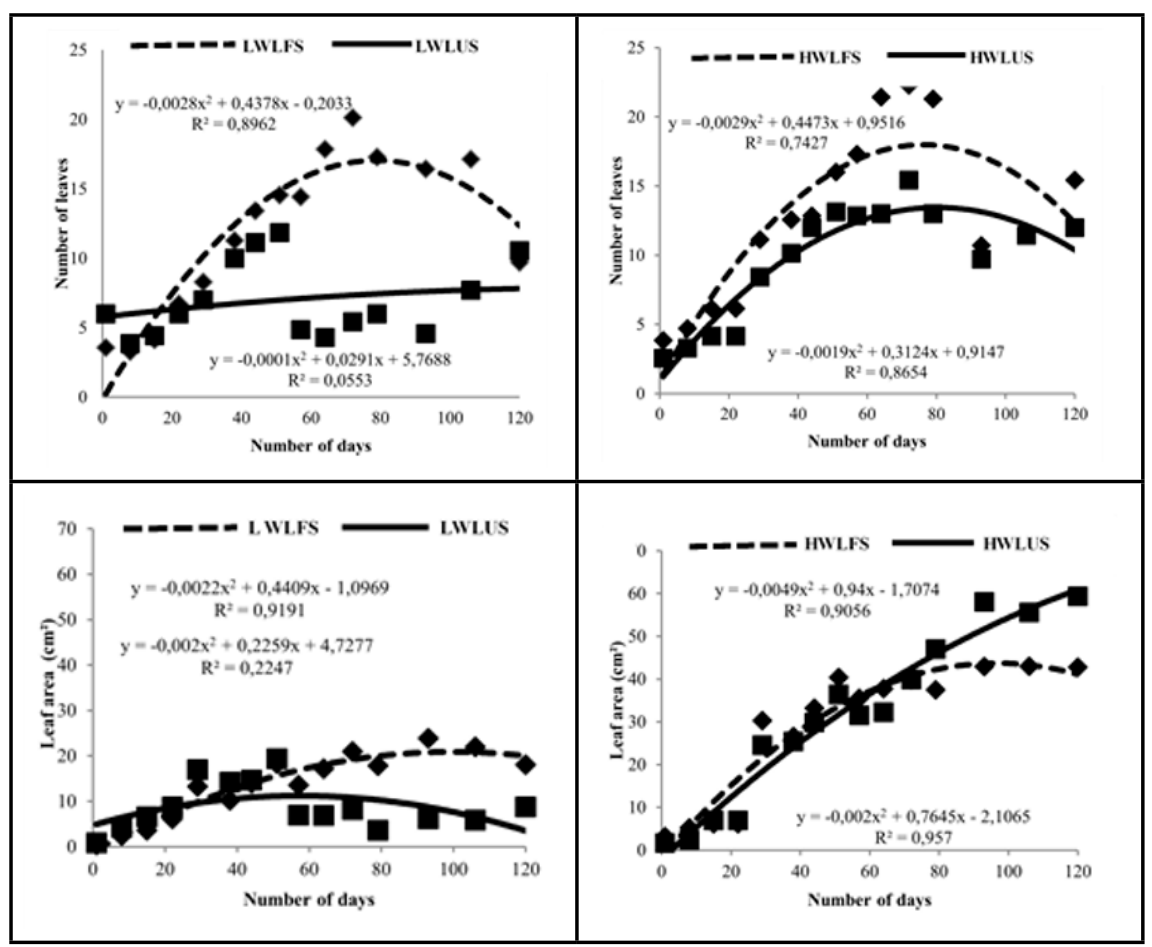

Figure 1. Number of leaves $(\mathrm{a}, \mathrm{b})$ and leaf area $(\mathrm{c}, \mathrm{d})$ in Nymphoides humboldtiana, during its development, submitted to treatments: low water level (water-saturated soil) (a, c) under full sun (LWLFS) and shaded conditions (LWLUS); high water level (30 cm water depth) (b, d) under full sun (HWLFS), and shaded conditions (HWLUS). Passo Fundo, UPF, 2009.

and luminosity provides an increase in nutrient uptake capacity (Pott \& Pott, 2000; Lacoul \& Freedman, 2006; Palma-Silva et al., 2008). Moreover, other factors are determinant in nutrient acquisition, such as the speed of flooding and water column depth (Lacoul \& Freedman, 2006; Richards \& Cao, 2012). In this case, the authors noticed no difference in the leaf area of plants grown under $30 \mathrm{~cm}$ water depth, both in places with high and low luminosity, discarding the idea of differential allocation of photoassimilates.

Petiole diameter showed no significant variation among treatments, but varied from 0.27 to $3.00 \mathrm{~mm}$ when leaves started emission, up to the flower emission, respectively. In this study, as also verified in the study with $N$. peltata (Yu \& Yu, 2010), the presence of green petioles was noticed (Figure 2), showing photoassimilate production in these submerged structures.

In aquatic-rooted-floating-leaved plants, both stem and petiole elongation occur in order to stimulate searches for luminosity and gases (James, 2008; Colmer \& Voesenek, 2009). No elongation of the petiole was verified in plants grown under low water depth (Table 1), regardless the presence of luminosity. When these plants are grown under high water depth, they presented longer petioles in shaded environment, due to the fact that the plant searches for luminosity. The authors observed that in each pot rotation, the leaves in pots near the border of sombrite showed positive phototaxis.

Petiole elongation, in order to keep floating leaves, is a positive value, considering plants for landscaping, since this trait shows that the aquatic plant can be used both in shallow lakes $(20$ to $30 \mathrm{~cm})$ built in residences with smaller gardens, and in up-to-300-cm

Table 1. Number of leaves, leaf area, petiole length at 120 days and total number of flowers of Nymphoides humboldtiana at 144 days according to two water levels and two luminosity conditions [full sun (FS) and shaded conditions (Sh)]. Passo Fundo, UPF, 2009.

\begin{tabular}{|c|c|c|c|c|c|c|c|c|}
\hline \multirow{2}{*}{$\begin{array}{l}\text { Water } \\
\text { level }\end{array}$} & \multicolumn{2}{|c|}{ Number of leaves } & \multicolumn{2}{|c|}{ Leaf area $\left(\mathrm{cm}^{2}\right)$} & \multicolumn{2}{|c|}{ Petiole length $(\mathrm{cm})$} & \multicolumn{2}{|c|}{ Number of flowers } \\
\hline & FS & $\mathbf{S h}^{2}$ & FS & Sh & FS & Sh & FS & Sh \\
\hline High & $12.90 \mathrm{a} \mathrm{A}^{3}$ & $9.68 \mathrm{aB}$ & $28.70 \mathrm{aA}$ & $30.54 \mathrm{a} \mathrm{A}$ & 18.95 a B & $22.02 \mathrm{aA}$ & $129.00 \mathrm{a} \mathrm{A}$ & $73.00 \mathrm{a} \mathrm{B}$ \\
\hline Low & $11.88 \mathrm{aA}$ & $6.91 \mathrm{bB}$ & $13.45 \mathrm{bA}$ & $8.80 \mathrm{bB}$ & $4.30 \mathrm{bA}$ & $3.90 \mathrm{bA}$ & $9.00 \mathrm{bA}$ & $0.00 \mathrm{bA}$ \\
\hline
\end{tabular}

1) High water level: $30 \mathrm{~cm}$ water depth. Low water level: water-saturated soil; 2) 50\% shading; 3) Averages followed by same lowercase letters in column and same uppercase letters in line do not differ from each other, Tukey test, 5.0\% probability level. 


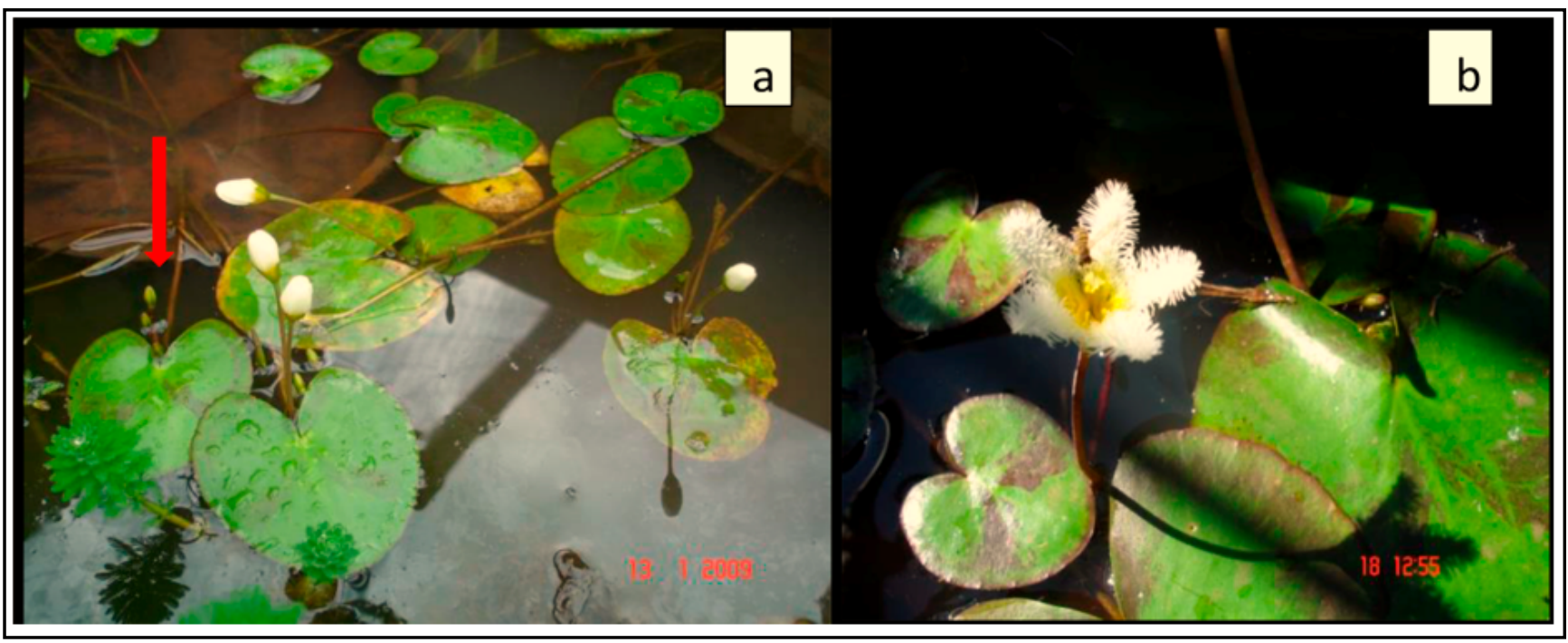

Figure 2. Flowers of Nymphoides humboldtiana. Flower buds (a), open flower (b). Passo Fundo, UPF, 2009.

lakes in natural environments (Pott \& Pott, 2000).

White Star flourished for a period of 144 days, from mid-spring to early autumn (November, 12 to April, 5). Flowering was favored in plants which were grown in full sun environment under high water depth, reaching up to 2 flowers/day/rizhome. No flowering emission was noticed in shaded environments without water depth (Table 1). At the beginning and the end of this period, low flower production was noticed. Flowering period of $N$. humboldtiana coincides with the flowering period of $N$. peltata (Wang et al., 2005) and $N$. aquatica (Richards et al., 2010), which also flourish seasonally.

Water depth determined flowering, followed by luminosity. This result shows plasticity in flowering response in relation to $N$. humboldtiana plant conduction in shaded environments by other plants, such as moist areas, lakes or gardens. In this study, plants did not flourish in water saturated soil (low water level) under shading. However, in the same condition of water, full sun, no significant difference was observed in number of flowers. Although showing a delicate appearance (Figure 2), flowering is a positive trait in its use as an ornamental plant, due to its abundance and long period, even though the number of flowers has decreased up to $43 \%$ when grown in a shaded place (Table 1), under high water level. White Star showed a 20-week flowering period, exceeding the observed fiveweek period in N. aquatica (Richards et al., 2010).

Using data obtained in this study, the authors recommend the use of $N$. humboldtiana for landscaping of shallow lakes, provided that the water level exceeds the level of the substrate and under full sun. This species also shows viability to be grown in shaded environments, when the main ornamental interest is to cover the water surface with leaves.

\section{ACKOWLEDGEMENTS}

To Dr. Lisete M. Lorini, from Laboratório de Entomologia da Universidade de Passo Fundo (Entomology Laboratory) for the caterpillar identification. To CNPq for productivity scholarship for Edson C. Bortoluzzi.

\section{REFERENCES}

BARCELOS, FRB; BOVE, CP. 2017. Flora do Rio de Janeiro: Menyanthaceae. Rodiguésia 68: 077-079.

BAVARESCO, A; GARCIA, MS; GRÜTZMACHER, AD; FORESTI, J; RINGENBER, GR. 2003. Biologia comparada de Spodoptera cosmioides (Walk.) (Lepidoptera: Noctuidae) em cebola, mamona, soja e feijão.Ciência Rural 33: 993-998.

BLIDAR, C. 2017. In vitro conservation of genetic resources of Nymphaea lotus varthermalis. Romanian Biotechnological Letters 22: 2-13. CATALOGUE OF LIFE. 2017. The catalogue of life parthership. Available at http://www. catalogueoflife.org/annual-checklist/2017/. Accessed January 03, 2018.

CHAMAS, CC; MATTHES, LAF. 2000. Métodos para levantamento de espécies nativas com potencial ornamental. Revista Brasileira de Horticultura Ornamental 6: 53-63.

COLMER, TD; VOESENEK, LACJ. 2009. Flooding tolerance: suites of plant traits in variable environments. Functional Plant Biology 36: 665-681.

DEVI, AS; THONGAM, B; HANDIQUE, PJ. 2015. Nymphaea rubra Roxc. Ex Andrews cultivated as an ornamental, food as vegetable in North Eastern region on India. Genetic Resources and Crop Evolution 62: 315-32.

FERREIRA, DF. 2014. Sisvar: a guide for its bootstrap procedures in multiple comparisons. Ciência e Agrotecnologia. Available at http://dx.doi.org/10.1590/S141370542014000200001. Accessed August 15, 2017.

FLORA DO BRASIL 2020 em construção. 2017. Jardim Botânico do Rio de Janeiro. Available at http://floradobrasil.jbrj.gov.br/. Accessed December 11, 2017.

IRGANG, BE; GASTAL JUNIOR, CVS. 1996. Macrófitas aquáticas da planície costeira do Rio Grande do Sul. Porto Alegre: UFRGS. $195 \mathrm{p}$.

JAMES, WK. 2008. Effects of lime-induced inorganic carbon reduction on the growth of three aquatic macrophyte species. Aquatic Botany 88: 99-104.

JUNQUEIRA, AH; PEETZ, MS. 2018. Sustainability in Brazilian floriculture: introductory notes to a systemic approach. Ornamental Horticulture 24: 155-162.

LACOUL, P; FREEDMAN, B. 2006. Environmental influences on aquatic plants in freshwater ecosystems. Environmental Review 14: 89-136.

MARWATS, K; KHAN, MA; AHMAD, M; ZAFAR, M. 2009. Nymphoides indica (L.) Kuntze, a new record for a Pakistan. Pakistan Journal of Botany 41: 2657-2660.

PALMA-SILVA, C; ALBERTONI, EF; 
TRINDADE, CRT; OLIVEIRA, SS 2008. Nymphoides indica (L.) O. Kuntze (Menyanthaceae) em um pequeno lago raso subtropical (Rio Grande, RS). Iheringia Série Botância 63: 249-256.

PRESTES, DKP; CUQUEL, FL; NEGRELLE, RRB. 2015. Ornamental potential of Tropaeolum pentaphyllum. Revista Brasileira de Horticultura Ornamental 23: 185-191.

POTT, VJ; POTT, A. 2000. Plantas aquáticas do pantanal. Corumbá MT: Embrapa. 250p.

RICHARDS, JH; DOW, M; TROXLER, T. 2010. Modeling Nymphoides architecture: a morphological analysis of Nymphaea aquatic (Menyanthaceae). American Journal of Botany 97: 1761-1771.

RICHARDS, JH; CAO, C. 2012. Germination and early growth of Nymphaea odorata at different water depths. Aquatic Botany 98: 12-19.

SILVA, DM; BUENO, AF; STECCA, CS; ANDRADE, K; NEVES, PMOJ; OLIVEIRA, MCN. 2017. Biology of Spodoptera eridania and Spodoptera cosmioides (Lepidoptera: Noctuidae) on different host plants. Florida Entomologist 100: 752-760.
SOUZA, VC; LORENZI, H. 2005. Botânica sistemática: guia ilustrado para identificação das famílias de Angiospermas da flora brasileira, baseado em APG II. Nova Odessa: Instituto Plantarum. 640p.

STRECK, EV; KÄMPF, N; DALMOLIN, RSD; KLAMT, E; NASCIMENTO, PC; SCHNEIDER, P. 2008. Solos do Rio Grande do Sul. 2. ed. Porto Alegre: Emater/Ascar. $107 \mathrm{p}$.

STUMPF, ERT; HEIDEN, G; BARBIERI, RL; FISCHER, SZ; NEITZKE, RS. 2009. Espécies nativas do bioma pampa para uso como folhagem de corte. Revista Brasileira de Horticultura Ornamental 14: 123-133.

STUMPF, ERT; SILVA, PS; ROMAGNOLI, ID; FISCHER, SZ; MARIOT, MP. 2015. Espécies nativas que podem substituir as exóticas no paisagismo. Ornamental Horticulture 21: 165-172.

TEDESCO, CD. 2011. Ecofisiologia e produção hortícola de Nymphoides indica e Myriophyllum aquaticum como estratégia para a valorização das áreas úmidas do planalto médio do Rio Grande do Sul. Universidade de
Passo Fundo. 145p (Ph.D. thesis).

TIPPERY, NP; LES, D. 2011. Phylogenetic relationships and morphological evolution in Nymphoides (Menyanthaceae). Systematic Botany 36: 1101-1113.

WANG, J; YU, D; WANG, Q. 2005. Reproductive consequences of interactions between clonal growth and sexual reproduction in Nymphoides peltata: a distylous aquatic plant. New Phytologist 165: 329-336.

ZHONGHUA, W; DAN, Y; MANGHUI, T; QIANG, W; WEN, X. 2007. Interference betweentwo floating-leaved aquatic plants: Nymphoides peltata and Trapabi spinosa. Aquatic Botany 86: 316-320.

YU, L; YU, D. 2010. Differential responses of the floating-leaved aquatic plant Nymphoides peltata to gradual versus rapid increases in water levels. Aquatic Botany 94: 71-76.

YU,H;NIU, Y;HU, Y; DU, D. 2014. Photosynthetic response of the floating-leaved macrophyte Nymphoides pelatata to a temporary terrestrial habitat and its implications of ecological recovery of lakeside. Avaliable at https://www. researchgate.net/publication/277684451. Accessed August 20, 2018. 